\section{An Efficient Method for Callus Culture and Shoot Regeneration of Garlic (Allium sativum L.)}

\author{
Xabier Barandiaran ${ }^{1}$ \\ Departamento de Microbiología, Facultad de Ciencias, Universidad de \\ Córdoba, Córdoba, Spain
}

Nieves Martín

Departamento de Microbiología, Facultad de Ciencias, Universidad de Córdoba, Córdoba, Spain

María Fernanda Rodríguez-Conde

Departamento de Mejora y Agronomía, Centro de Investigación y Formación Agraria, Córdoba, Spain

Antonio Di Pietro

Departamento de Genética, Facultad de Ciencias, Universidad de Córdoba, Córdoba, Spain

\section{Jesus Martín}

Departamento de Microbiología, Facultad de Ciencias, Universidad de Córdoba, Córdoba, Spain

Additional index words. organogenesis, tissue culture, in vitro, callus production, auxin, cytokinin

\begin{abstract}
The influence of different callus induction media on the regeneration process in garlic was tested. The auxin 2,4 dichlorophenoxyacetic acid frequently used in garlic tissue culture was found to be detrimental when used at the levels described in the literature. However, combinations of growth regulators commonly used for dicot tissue culture produced high levels of callus induction and regeneration that could be used efficiently in a transformation program.
\end{abstract}

Cultivated genotypes of garlic are sterile, limiting commercial development of this species to selection and multiplication of spontaneous or induced mutants. Given the absence of other methods of gene transfer, transformation holds a great potential for directed improvement in garlic. However, the use of this tool depends on the availability of a highly efficient system for callus production and regeneration that is still lacking for this crop.

\section{Materials and Methods}

Our study tested the effects of several media on callus formation and regeneration in the Spanish garlic cultivar Rojo de Cuenca. The explants used were axenic root tips obtained from micropropagated material (Bhojwani, 1980). Root sections were cultured in sterile 9$\mathrm{cm}$ petri dishes each containing $25 \mathrm{~mL}$ of B5 medium (Gamborg et al., 1968) and combinations of growth regulators (Table 1). Media were supplemented with $3 \%$ sucrose, solidi-

Received for publication 25 Feb. 1998. Accepted for publication 15 July 1998 . The cost of publishing this paper was defrayed in part by the payment of page charges. Under postal regulations, this paper therefore must be hereby marked advertisement solely to indicate this fact.

${ }^{1}$ To whom reprint requests should be addressed. fied with $0.8 \%$ Bacto-Agar (Difco, Detroit) and adjusted to $\mathrm{pH} 5.7$ before autoclaving. For callus induction, cultures were incubated at 25 ${ }^{\circ} \mathrm{C}$ in the dark for 3 months, and subcultured to fresh medium for another 2 months. For the brief regeneration tests, portions of callus ( 150 $\pm 10 \mathrm{mg}$ fresh weight) obtained in each of the callogenic media (media 1-8, Table 1) were
"Mean values for media 4-8. transferred to the four organogenic media (media I-IV, Table 1) and incubated in a growth chamber at $25 \pm 2{ }^{\circ} \mathrm{C}$, under a 16-h photoperiod with fluorescent light $\left(55 \mu \mathrm{mol} \cdot \mathrm{m}^{-2} \cdot \mathrm{s}^{-1}\right)$.

In the first experiment (A), a completely randomized design was used with three media (callus formation media 1-3, Table 1) containing 2,4-dichlorophenoxyacetic acid (2,4-D). In the second experiment (B), a concentration gradient of $\alpha$-naphthaleneacetic (NAA) was used (callus formation media 4-8, Table 1). Each replication (10 per treatment) consisted of one petri dish with three explants. The percentage of callus formation was measured after 12 weeks. The experimental design for the third experiment (C) was completely randomized with four media (organogenic media I-IV, Table 1). Ten replicate petri dishes, each with three calli, were used for each of the 32 callus formation medium $\times$ regeneration medium combinations. Plant regeneration was recorded after 4 months of culture (without transfer) and the two following traits were evaluated: percentage of organogenic explants and shoot production yield, defined as the number of shoots per gram of callus.

\section{Results and Discussion}

In Expt. A, callus formation was greatest on the medium containing BA, NAA, and a low concentration of 2,4-D, and least on that containing BA and the higher concentration of 2,4-D without NAA. Regeneration, however, was equally good on both of these media. Few shoots formed on media containing no NAA, whereas NAA stimulated shoot formation (Table 1). Orthogonal contrasts of the data from Expt. B indicated no significant differences among NAA concentrations in their effects on callus formation or regeneration, but shoot formation declined with increasing concentration of NAA (Fig.1, Table 2). Mean values for callus formation and regeneration for all five treatments in Expt. B were not significantly different from those for the best treatment in Expt. A, and shoot formation for the best treatment in Expt. B (10.7 $\mu \mathrm{M}$ NAA)

Table 1. Effects of callus formation media and regeneration media on percentage of explants producing callus, percentage of organogenic explants, and shoots produced per gram of callus in A. sativum.

\begin{tabular}{|c|c|c|c|c|c|c|c|c|}
\hline \multirow[t]{3}{*}{ Expt. } & \multirow[t]{3}{*}{ Medium } & \multicolumn{4}{|c|}{$\begin{array}{c}\text { Contents of medium } \\
\left(\mu_{\mathrm{M}}\right)\end{array}$} & \multirow{3}{*}{$\begin{array}{c}\text { Callus formation } \\
(\%)\end{array}$} & \multirow[t]{2}{*}{$\begin{array}{c}\text { Regeneration } \\
(\%)\end{array}$} & \multirow[t]{2}{*}{ Shoots/g } \\
\hline & & & & Callu & s formo & & & \\
\hline & & BA & $2,4-\mathrm{D}$ & NAA & $2 \mathrm{iP}$ & & & \\
\hline A & 1 & --- & 1.40 & --- & 2.5 & $57.1 \mathrm{~b}^{\mathrm{z}}$ & $16.6 \mathrm{~b}$ & $0.9 \mathrm{~b}$ \\
\hline A & 2 & 13.3 & 1.40 & --- & -- & $29.9 \mathrm{c}$ & $36.2 \mathrm{a}$ & $3.7 \mathrm{~b}$ \\
\hline A & 3 & 13.3 & 0.14 & 10.7 & --- & $93.4 \mathrm{a}$ & $32.2 \mathrm{ab}$ & $16.2 \mathrm{a}$ \\
\hline B & 4 & 13.3 & --- & 10.7 & --- & --- & --- & $10.7 \mathrm{ab}$ \\
\hline B & 5 & 13.3 & --- & 21.5 & --- & --- & --- & --- \\
\hline B & 6 & 13.3 & --- & 32.2 & --- & $79.2 \mathrm{a}^{*}$ & $62.5 \mathrm{a}^{*}$ & --- \\
\hline B & 7 & 13.3 & --- & 42.9 & --- & --- & --- & --- \\
\hline $\mathrm{B}$ & 8 & 13.3 & --- & 53.7 & --- & --- & --- & --- \\
\hline \multicolumn{9}{|c|}{ Regeneration media } \\
\hline & & $\mathrm{BA}$ & $\mathrm{K}$ & IAA & TIBA & & & \\
\hline C & I & --- & --- & --- & --- & --- & 54.7 & 5.1 \\
\hline $\mathrm{C}$ & II & 13.3 & --- & --- & --- & --- & 53.8 & 8.8 \\
\hline $\mathrm{C}$ & III & --- & 46.50 & 11.4 & --- & --- & 45.4 & 7.9 \\
\hline $\mathrm{C}$ & IV & --- & --- & --- & 10 & --- & 45.3 & 5.5 \\
\hline
\end{tabular}

${ }^{2}$ Mean separation within columns by Duncan's multiple range test at $P \leq 0.05$ 


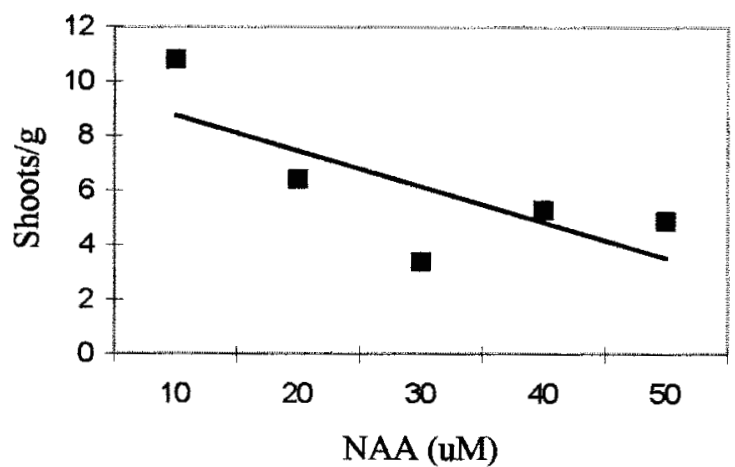

Fig. 1. Effect of concentration of NAA on shoot production per gram of callus in A. sativum tissue cultures. $\mathrm{y}=10.02-1.3 \mathrm{x}, r^{2}=0.53$ (Expt. B).

Table 2. F values of orthogonal contrast analysis for shoots/g produced from $A$. sativum callus.

\begin{tabular}{lc}
\hline \hline Source & Shoots/g \\
\hline Callus formation media & $0.022^{*}$ \\
Linear & $0.016^{*}$ \\
Quadratic & 0.042 \\
Regeneration media & 0.557 \\
\hline
\end{tabular}

Significant at $P \leq 0.05$

Table 3. F values from ANOVA for callus formation, shoot regeneration, and shoots/gram of A. sativum tissue cultures.

\begin{tabular}{lccc}
\hline Source & Callus formation & Regeneration & Shoots/g \\
\hline Callus formation media (A) & $15.07^{* * * *}$ & $4.59^{*}$ & $2.87^{*}$ \\
Regeneration media (B) & --- & 0.37 & 0.71 \\
A $\times$ B & --- & --- & 1.60 \\
\hline
\end{tabular}

**** Significant at $P \leq 0.05$ or 0.001 . All others nonsignificant.

did not differ significantly from that for the best treatment in Expt. A. Neither percentage of regeneration nor number of shoots per gram differed significantly among the media used in Expt. C.

In previous work with garlic callus cultures, 2,4-D was used at concentrations ranging from 0.5 to $50 \mu \mathrm{M}$. Our study included two media containing $1.4 \mu \mathrm{M}$ 2,4-D (media 1 and 2 ) and one medium containing $0.14 \mu \mathrm{M} 2,4-\mathrm{D}$ (medium 3). Media 1 and 2 both produced the poorest levels of callus formation and among the lowest values for both regeneration traits.
Medium 3 produced the best callus formation and the highest number of shoots per gram, although the percentage of regenerating explants was reduced. Media without 2,4-D showed better values of callus formation than media 1 and 2, and produced percentages of shoot regeneration as high as 62.5 .

By comparing pairs of media differing in a single component, some specific effects were detected. Media 1 and 2 differed in the quality and quantity of the cytokinin used. High doses of BA appeared to promote regeneration but reduce callus formation. By comparing callus formation media without 2,4-D (medium 4-8) with medium 3 , we conclude that low levels of 2,4-D increase the percentage of explants producing callus and the number of regenerated shoots per gram of callus.

Our results show that 2,4-D is not essential for callus induction and regeneration and can be detrimental when used in concentrations similar to those described in previously published protocols (Havránek and Novák, 1973; Kehr and Schaeffer, 1976; Koch et al., 1995; Novak, 1990). The combination of high concentrations of NAA and BA produced excellent results in terms of percentage of callus formation and shoot regeneration and, in some cases, good levels of shoots per gram.

Analysis of variance of regeneration media showed no significant differences among the four treatments tested (Table 3). The callus formation media differed significantly for both regeneration traits (percentage of regenerating explants and number of shoots per gram) (Table 1), whereas organogenic media did not (Table 2), revealing the importance of the medium used to initiate callus on the tissue culture process. After analyzing all the data obtained, we recommend medium 3 for callus induction and medium II for shoot regeneration.

\section{Literature Cited}

Bhojwani, S.S. 1980. In vitro propagation of garlic by shoot proliferation. Scientia Hort. 13:47-52. Gamborg, O.L., R.A. Miller, and K. Ojima. 1968. Nutrient requirements of suspension cultures of soybean root cells. Expt. Cell. Res. 50:151.

Havránek, P. and F.J. Novák. 1973. The bud formation in callus cultures of Allium sativum L. Z. Pflanzenphysiol. 68:308-318.

Kehr A. E. and G.W. Schaeffer. 1976. Tissue culture and differentiation of garlic. HortScience 11:422-423.

Koch, M., Z. Tanami, and R. Salomon. 1995. Improved regeneration of shoots from garlic callus. HortScience 30:378.

Novák, F. J. 1990. Allium tissue culture, p. 234-250. In: H.D. Rabinowitch and J.L Brewster (eds.). Onions and allied crops. CRC Press, Boca Raton, Fla. 